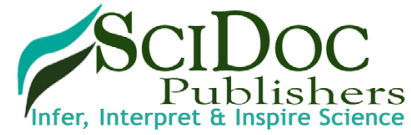

\section{A Study on Knowledge, Attitude, Behaviour and Practice (KABP) towards HIV/AIDS in Manipur,} India

Research Article

Lamkang $\mathrm{SA}^{1^{*}}$, PC Joshi', MM Singh ${ }^{3}$

${ }^{1}$ Research Associate, Public Health Foundation of India, Institutional Area, Gurgaon, India.

${ }^{2}$ Professor, Department of Anthropology, University of Delhi, Delhi, India.

${ }^{3}$ Professor, Centre for Community Medicine, Maulana Azad Medical College, New Delhi, India.

\title{
Abstract
}

Background: Since its first detection in Manipur in the early 1990's among a group of injecting drug users, HIV/AIDS has spread rapidly into the general population. Manipur is now one of the six high HIV/AIDS prevalence states in India. According to Manipur State AIDS control society (MSACS), HIV/AIDS is also a highly misunderstood and stigmatised disease in the state.

Objective: The purpose of this study is to assess and understand knowledge, attitude, behaviour and practice towards HIV/AIDS in Manipur.

Methods: A cross sectional descriptive study using random sampling was carried out among the local community in Chandel district, Manipur, India. A semi-structured interview on KABP was conducted among 100 study participants who were non-HIV. Data were analysed using SPSS 12.0.

Results: The study found a good level of knowledge on HIV/AIDS transmission and prevention, but there were misconceptions. There was discrepancy between knowledge and attitude, and between knowledge and behaviour/practice. Sociocultural and religious misconceptions about the disease and towards people living with HIV/AIDS (PLHA) was observed to take precedence over medical facts. In addition, local communities rely heavily on unreliable sources such as local gossip and church for HIV/AIDS information and this was found to be the main cause for misconception and stigmatisation against HIV/AIDS and PLHA. The study population was also found to be at risk for HIV infection as practice of safe sex was inconsistent and poorly maintained.

Conclusion: The findings suggest that there is a strong need to address socio-cultural and religious misconceptions about HIV/AIDS in Manipur. Accurate and reliable information on HIV/AIDS is needed for the dissemination programmes. To help mitigate misconceptions and stigmatisation, socio-religious leaders who play an important role in influencing community's perception and behaviour towards HIV/AIDS need to be properly educated about the disease. The study identified a need for connecting local communities with reliable sources of information pertaining to HIV/AIDS and to mobilise the communities to adopt safe sex practices.

Keywords: HIV/AIDS; PLHAs'; KABP; Stigma and Discrimination; Community; Misconceptions; Culture; Society; Awareness; Condom.

\section{Introduction}

Human immunodeficiency virus (HIV) and acquired immune deficiency syndrome (AIDS) is a serious global public health issue with millions of people getting newly infected every year [1-4]. The effort to find curable medicine have so far eluded medical science. Anti-retro viral therapy (ART or ARV), a highly suppressive therapy is the closest discovery in the fight against HIV/AIDS.
This discovery has brought a paradigm shift in the biological manifestation of the disease by making it a debilitating chronic disease. While ART has certainly prolonged life expectancy of people living with HIV/AIDS (PLHA), it has also increased the biological and sociological burdens associated with the disease for longer duration. This is especially true in developing countries where the biological understanding of HIV/AIDS is often based on socio-cultural beliefs. Incorrect knowledge and social

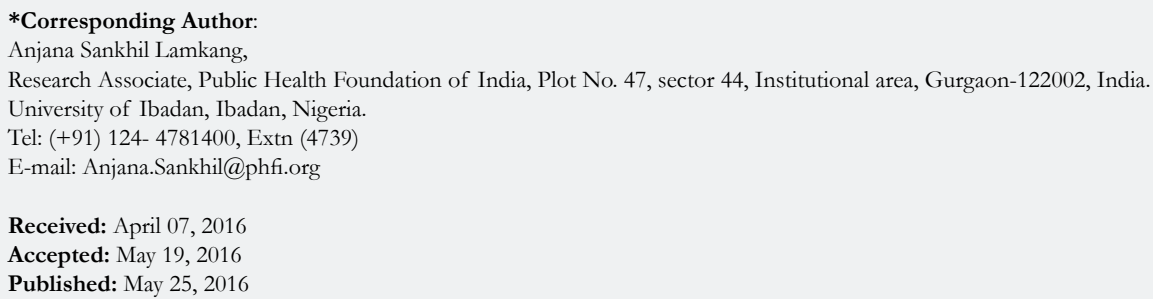

Copyright: Lamkang $\mathbf{S A}^{\circ}$ 2016. This is an open-access article distributed under the terms of the Creative Commons Attribution License, which permits unrestricted use, distribution and reproduction in any medium, provided the original author and source are credited. 
misconceptions due to physiological and biological complexity of HIV/AIDS are responsible for stigmatisation of PLHA in many developing countries $[2,3,5-7]$. This stigmatisation is compounded by the fact that the disease is predominantly concentrated among the already stigmatised people such as sexually promiscuous, injecting drug users (IDU), and homosexuals $[8,9]$.

In countries like India where socio-cultural ties are very strong, social misconceptions and misgivings about HIV/AIDS have far-reaching implications on PLHA. Consequently, PLHA feel reluctant to either seek timely medical help or take preventive measures for fear of discrimination and social ostracism thereby putting family and community at risk for HIV infection [10]. Therefore, in the absence of any immediate curable medicine, prevention of HIV/AIDS transmission through correct knowledge, positive attitude, safe behaviours and practices are the only practical ways to contain it $[11,12]$. However, since HIV/AIDS is a disease that is largely transmitted through sexual behaviour, preventive measures have to be carefully planned so that they do not conflict with the individuals' beliefs and values in a cultural context $[6,13,14]$. The symbolic meanings, values and morality attached to sexual acts and sexual relationships must be considered in a cultural context for any effective HIV preventive measures [15].

Manipur is located in the north eastern part of India bordering Myanmar on the east. Manipur constitutes less than $0.2 \%$ of India's total population but is home to $8 \%$ of India's total PLHA. It is also one of the six high HIV/AIDS prevalence states in India with the highest estimated HIV adult prevalence rate of $1.40 \%[16,17]$. In the initial stage, HIV/AIDS in Manipur was largely confined to IDUs. But over the last two decades, it has rapidly spread into the general population through heterosexual transmission [16]. Despite Manipur having one of the highest HIV adult prevalence states in India, research studies on HIV/ AIDS is very limited. The existing HIV/AIDS related NGOs, community based organisations (CBOs) and government agencies are primarily focussed on the immediate programmes and interventions specific to PLHA while research on the same remains largely neglected. However, unless contextual research is done to understand local perspectives of the disease including sexual behaviour and practices, and using such research findings to formulate preventive measures, the fight against HIV/AIDS may not bring the desired result.

Against this backdrop, the purpose of the study is to assess and understand the community's knowledge, attitude, behaviour and practice towards HIV/AIDS and the response towards the disease.

\section{Materials and Methods}

A cross sectional study on KABP was carried out in Chandel, Manipur. This study was part of a larger study which assessed the quality of life and needs of HIV/AIDS patients in Manipur from May to November 2008. Chandel is a small town in the south of Manipur and is compactly inhabited by tribal populations belonging to the Naga ethnic group who are predominantly Christians. Although non-Naga communities from within and outside Manipur also settle in the town temporarily for business purposes, they constitute a very small negligible population. To maintain homogeneity, the study targets only the indigenous inhabitants of the town belonging to the Naga ethnic group.

\section{Selection of Study Site and Study Participants}

The aim was to recruit 100 non-HIV study participants from Chandel town. Prior to the selection of the sample, list of PLHA in the town was obtained from local NGO centres so as to be able to identify and exclude them as potential study participants. To get the study sample, a list of around 2000 households in all the villages/colonies in the town was obtained from the Chandel Sub-Divisional office (SDO). For administrative purposes, the town is divided into 20 separate colonies/villages within a $3 \mathrm{Km}$ radius. The size of the colonies/villages ranged from a small colony/village with only 30 households to the biggest with 280 households. Village boundaries in many cases were overlapping and did not have clear demarcation. For instance, two or more houses coming under different village administrations were geographically positioned close to each other. Additionally, a few villages and houses that were located on the outskirts and mountainous parts of the town were excluded from the study for practical reason. As a result, to randomly pre-select households based on village/colony from the list and locate them on ground was not practical for a lone researcher.

Using villages/colonies located in the heart of the town, the study site then was divided into 10 geographical zones with approximately equal numbers of households to be representative of the town. Ten households were selected from each zone. Within each zone, every $10^{\text {th }}$ household was selected. From each selected household, only one adult (18 years or more) was selected for interview. If that person refused, the whole household was replaced by the next household. Thus, a total of 100 participants from 100 households were interviewed for the study.

There were altogether 7 households where the selected participants refused to participate while in another 5 households, no adult members were available at the time of field visits. The reason for refusal in five cases was to do with the subject HIV/AIDS while in the other two cases, the respondents admitted being illiterate with limited knowledge on the subject.

\section{Informed Consent}

Informed consent for each participant was obtained verbally prior to the interview. The questionnaire was administered through face to face interview. This was supplemented by qualitative inputs generated through participant observation and personal interaction with the study participants. This study was part of a Ph.D work carried out under the Department of Anthropology, University of Delhi.

\section{Data Analysis}

Data were analysed using SPSS 12.0. Qualitative information was not formally analysed for this paper, but observations are incorporated into the discussion section to help provide participants' perspectives about HIV/AIDS related knowledge, attitude, behaviour and practices. 


\section{Results}

The findings are presented as the proportion of study respondents replying yes to each question, or agreeing with given statements.

\section{Socio-demographic profile of study participants}

From Table 1, Out of a total of 100 respondents, 50 were women and 50 men. The mean age of respondents was 32 years of age. More than half of the respondents were between 18 and 30 years old and about a quarter of them were between 31 and 40 years old.

Around $60 \%$ of respondents had completed secondary education or higher, and one in 8 were illiterate. The majority of the respondents were married, and most reported their occupation as housewife, student, or unemployed. All respondents follow Christianity.

\section{Knowledge about HIV/AIDS}

Although almost all respondents (99\%) had heard of AIDS, relatively few correctly knew what HIV and AIDS was $(6 \%$ and $22 \%$ respectively). More respondents identified AIDS correctly than HIV. When respondents were asked if they consider HIV and AIDS as the same, $47 \%$ respondents differentiate the two as different from one another.

Pertaining to the cause of HIV/AIDS, $59 \%$ respondents correctly named a virus as the cause.

\section{Knowledge about HIV/AIDS transmission}

From Table 2, more than 96\% respondents correctly knew the primary modes of HIV transmission via unprotected sex, infected blood transfusion and sharing infected syringes. About 86-89\% respondents knew HIV transmission through infected mother to child during pregnancy and breastfeeding. However, as compared to the first three, knowledge of infected mother to child transmission during pregnancy and breastfeeding was slightly lower. Despite possessing good knowledge on HIV transmission, it was marred with misconceptions as a significant number of respondents (in the range of 11-40\%) incorrectly thought HIV could also be transmitted through a mosquito or insect bite,

Table 1. Socio-demographic profile of the study participants.

\begin{tabular}{|c|c|c|}
\hline S1. No. & Name of variables & Total no. of respondents $(\mathrm{N}=100)$ \\
\hline 1 & $\begin{array}{c}\text { Gender } \\
\text { Male } \\
\text { Female }\end{array}$ & $\begin{array}{l}50 \\
50 \\
\end{array}$ \\
\hline \multirow[t]{2}{*}{2} & Mean age of respondents & 32 years \\
\hline & $\begin{array}{c}\text { Age of respondents } \\
18-30 \text { years } \\
31-40 \text { years } \\
41-50 \text { years } \\
51-60 \text { years } \\
\text { 60-above years } \\
\end{array}$ & $\begin{array}{c}53 \\
26 \\
14 \\
6 \\
1\end{array}$ \\
\hline 3 & $\begin{array}{c}\text { Education } \\
\text { None/illiterate } \\
\text { Primary/intermediate } \\
\text { Matriculation } \\
\text { Secondary } \\
\text { Graduation } \\
\text { Post-graduate }\end{array}$ & $\begin{array}{c}13 \\
22 \\
6 \\
30 \\
25 \\
4\end{array}$ \\
\hline 4 & $\begin{array}{c}\text { Marital status } \\
\text { Married } \\
\text { Unmarried } \\
\text { Separated } \\
\text { Widowed } \\
\end{array}$ & $\begin{array}{c}55 \\
39 \\
1 \\
5 \\
\end{array}$ \\
\hline 5 & $\begin{array}{c}\text { Occupation } \\
\text { Employed } \\
\text { Unemployed } \\
\text { Social worker } \\
\text { Small time business } \\
\text { Housewife } \\
\text { Student } \\
\text { Retired } \\
\end{array}$ & $\begin{array}{c}7 \\
24 \\
5 \\
7 \\
29 \\
26 \\
2 \\
\end{array}$ \\
\hline 6 & $\begin{array}{c}\text { Religion } \\
\text { Christian } \\
\text { Others }\end{array}$ & $\begin{array}{l}100 \\
\text { Nil }\end{array}$ \\
\hline
\end{tabular}


Table 2. Knowledge on HIV/AIDS transmission, prevention, symptoms, PLHA \& source of information.

\begin{tabular}{|c|c|c|}
\hline S1. No. & Questions & Yes $\%(N=100)$ \\
\hline 1 & $\begin{array}{l}\text { Can HIV/AIDS be transmitted by } \\
\text { - } \quad \text { Unprotected sex } \\
\text { - } \text { Sharing infected needle } \\
\text { - } \text { Infected blood transfusion } \\
\text { - } \quad \text { Sharing towels } \\
\text { - } \quad \text { By kissing/hugging } \\
\text { - } \quad \text { Mosquito/insect bite } \\
\text { - } \quad \text { Infected mother to child transmission during pregnancy } \\
\text { - } \quad \text { Breast feeding through infected mother } \\
\text { - } \quad \text { Coughing/sneezing }\end{array}$ & $\begin{array}{l}100 \\
97.0 \\
99.0 \\
13.0 \\
29.0 \\
40.0 \\
89.0 \\
86.0 \\
11.0\end{array}$ \\
\hline 2 & Can HIV/AIDS be prevented? & 97.0 \\
\hline 3 & $\begin{array}{l}\text { What are the different ways by which HIV/AIDS could be prevented? } \\
\text { - To be loyal to your partner } \\
\text { - To always use condom correctly } \\
\text { - To always use disposable syringes and needles } \\
\text { - To always use sterilize instruments during surgery } \\
\text { - To always receive blood from licensed blood bank only }\end{array}$ & $\begin{array}{l}97.0 \\
90.0 \\
97.0 \\
95.0 \\
91.0\end{array}$ \\
\hline 4 & $\begin{array}{l}\text { What are the commonly observed symptoms of HIV/AIDS in PLHA? } \\
\text { - Fever/cough } \\
\text { - Diarrhea } \\
\text { - Weight loss } \\
\text { - Swellings in groins \& armpits } \\
\text { - } \text { Rash on the skin } \\
\text { - Loss of appetite and complexion } \\
\text { - OI like T.B/ cancer }\end{array}$ & $\begin{array}{l}70.0 \\
68.0 \\
90.0 \\
66.0 \\
79.0 \\
90.0 \\
68.0\end{array}$ \\
\hline 5 & Do you know anyone infected with HIV/AIDS? & 85.0 \\
\hline 6 & $\begin{array}{l}\text { How did you know about it? } \\
-\quad \text { Local gossips } \\
-\quad \text { Friends } \\
-\quad \text { Family } \\
\text { - } \quad \text { Medical personnel }\end{array}$ & $\begin{array}{l}81.0 \\
77.0 \\
66.0 \\
25.0\end{array}$ \\
\hline 7 & Is there anyone in your immediate locality infected with HIV/AIDS? & 67.0 \\
\hline 8 & $\begin{array}{l}\text { How did you know about it? } \\
-\quad \text { Local gossips } \\
-\quad \text { Friends } \\
-\quad \text { Family } \\
-\quad \text { Medical personnel }\end{array}$ & $\begin{array}{c}60.0 \\
58 . \\
5.0 \\
14.0\end{array}$ \\
\hline 9 & Have you known someone who has died of AIDS? & 92.0 \\
\hline 10 & $\begin{array}{l}\text { How did you know about it? } \\
-\quad \text { Local gossip } \\
-\quad \text { Friends } \\
-\quad \text { Family } \\
-\quad \text { Medical personnel } \\
\end{array}$ & $\begin{array}{l}84.0 \\
82.0 \\
80.0 \\
40.0 \\
\end{array}$ \\
\hline 11 & $\begin{array}{l}\text { What is your source of information on HIV/AIDS } \\
-\quad \text { Radio } \\
-\quad \text { Television } \\
-\quad \text { Newspaper } \\
-\quad \text { Street plays/sumang lila } \\
-\quad \text { Local gossips } \\
-\quad \text { Church }\end{array}$ & $\begin{array}{l}77.0 \\
43.0 \\
48.0 \\
45.0 \\
96.0 \\
87.0\end{array}$ \\
\hline
\end{tabular}

$\%=$ percentage; $\mathrm{N}=$ No. of respondents

kissing or hugging, sharing towels and coughing or sneezing.

\section{Knowledge about HIV/AIDS prevention}

With respect to the mode of prevention (Table 2), a very high percentage of $90-97 \%$ respondents reported that HIV could be prevented by being loyal to one's sexual partner, to always use a condom correctly, always use disposable syringes and needles, sterilized instruments during surgery, and to receive blood from only trusted licensed blood banks. Though the knowledge on mode of prevention was high, there is still a need to improve on the knowledge of condom safety, getting blood from licensed blood, using sterilized instruments during surgery.

\section{Knowledge on commonly observed symptoms of HIV/ AIDS}

About $90 \%$ respondents reported weight loss, loss of appetite 
and complexion as the most commonly observed symptoms manifested by PLHA. This was followed $79 \%$ respondents reporting developing a rash on the skin while $66-70 \%$ respondents reported fever/cough, diarrhoea, opportunistic infections (OI) like TB or cancer and swellings in the groins or armpit. From the Table 2, majority of respondents had a fair knowledge of HIV/ AIDS symptoms especially pertaining to weight loss and loss of appetite.

\section{Knowledge of PLHA}

About 85\% respondents reported knowing someone infected with HIV/AIDS. Local gossip was reported as the main medium through which the HIV/AIDS status of a person gets spread in the locality. As can be observed from Table 2, 66-81\% cited local gossip, friends and family members as the source for receiving such information. A considerable number of respondents $(22 \%)$ also reported knowing the HIV/AIDS status of an individual from medical personnel.

Two thirds of respondents knew someone infected with HIV/ AIDS in the immediate locality. About 54-60\% respondents reported local gossip, friends and family as the source for receiving information on someone's HIV/AIDS status. A significant number of respondents $(14 \%)$ also reported medical personnel as the source.

Respondents were asked if they know of anyone who has died of AIDS to which $92 \%$ respondents replied in the affirmative. $80-84 \%$ respondents cited local gossip, friends, and family as the main source for learning such information. A considerable number of respondents (40\%) also reported knowing it from medical personnel.

\section{Source of HIV/AIDS information}

From Table 2, local gossip (96\%) was the main source of receiving HIV/AIDS information in the locality. This was closely followed by church (87\%). Information received from media sources other than radio $(77 \%)$ such as television, newspaper and, street plays/ sumang lila was comparatively low at $43-48 \%$.

\section{Attitude towards HIV/AIDS and safer sex}

Attitudes towards HIV/AIDS were generally negative. As indicated in Table 3, more than half of the respondents $(55 \%)$ considered AIDS as punishment of God for bad behaviour. The majority of respondents (83-89\%) agreed with the statements that HIV/AIDS was mainly a problem of immoral behaviour and IDU. About 61-69\% respondents said PLHA should be ashamed of themselves and should not get married.

About 93-97\% respondents agreed with the statement that HIV testing prior to marriage is a must and they would not marry HIV positive person. Another 62-69\% said PLHA should have a separate health centre and they should be isolated to prevent further transmission. A significant proportion of $37 \%$ respondents also said PLHA should not be operated for any surgical problem to avoid contaminating the instruments and putting others at risk for HIV infection. Regarding the future of PLHA, 77\% respondents said they were destined to die sooner. More than half of the respondents reported preferring not to mingle with HIV/
AIDS infected people (53\%) and said they would feel ashamed if they were infected with the virus $(75 \%)$.

The attitude towards sexual behaviour was conservative. Two thirds of respondents $(69 \%)$ were against sexual intercourse outside marriage. A significant number of respondents $(18 \%)$ agreed that it was alright to have pre-marital sex. As far as the attitude towards the use of condom was concerned, there was mixed response. Slightly more than half of the respondents $(52 \%)$ reported that it was personal choice and they would not have issue with it.

\section{Behaviour and practices}

From Table 4, a small percentage of respondents had one or more blood transfusions (7\%) and admitted abusing non-medical drugs $(4 \%)$.

When it comes to sexual behaviour, a majority of them $(70 \%)$ reported having been physically intimate with someone. This high proportion is reflective of the fact that 55\% respondents were married. Notwithstanding this fact, a significant number of respondents (15\%) reported having sex with non-regular sexual partners. Of this, only about $18 \%$ of them use a condom consistently. Among married respondents, about 25\% reported using family planning. Pertaining to the use of a condom, $43 \%$ respondents said they would be able to ask their sexual partners to use a condom during sex. Interestingly, a total of only $11 \%$ respondents considered themselves at risk for HIV infection.

Though HIV/AIDS is a serious public health issue in Manipur, only 45\% respondents reported having attended an HIV/AIDS awareness programme at least once in their life. Similarly, for HIV testing, only $45 \%$ had ever taken the test and these were mostly married women who took the test during routine ANC check. Less than half of the respondents expressed willingness to undertake the test if given the chance to do so.

With respect to discriminatory behaviour and practices, two thirds of respondents admitted hearing gossip against PLHA while $59 \%$ admitted that PLHA were often denied religious positions in society. A significant number of respondents (15\%) also said PLHA were often humiliated or insulted in society. In addition, $32 \%$ respondents said if they have PLHA in the family, they would assign separate utensils for them.

Finally, majority of the respondents said they would confide in their parents, spouse, with close persons and adult children if they were infected with HIV/AIDS. 25-38\% respondents said they would confide with their friends and neighbours if infected with $\mathrm{HIV} / \mathrm{AIDS}$.

\section{Discussion}

The present study found that though almost all respondents have heard of the word AIDS, many of them did not correctly know what AIDS exactly is about. A study of knowledge and attitudes among college students towards HIV/AIDS in Kerala reported similar findings [5]. In addition, not only were the respondents unable to distinguish between HIV and AIDS, a considerable number of respondents did not even know what HIV is when 
Table 3. Attitudes towards HIV/AIDS.

\begin{tabular}{|c|l|c|}
\hline Sl. No. & \multicolumn{1}{|c|}{ Attitudinal statements } & Agree \% (N=100) \\
\hline 1 & AIDS is a punishment of God for bad behaviour & 55.0 \\
\hline 2 & HIV/AIDS is mainly a problem of immoral behaviour & 83.0 \\
\hline 3 & HIV/AIDS is a problem with IDUs & 89.0 \\
\hline 4 & PLHA should be ashamed of themselves & 61.0 \\
\hline 5 & PLHA should not get married & 69.0 \\
\hline 6 & HIV testing is a must prior to marriage & 97.0 \\
\hline 7 & There should be separate health centre for PLHA & 85.0 \\
\hline 8 & PLHA should be isolated to prevent further transmission & 62.0 \\
\hline 9 & I would prefer not mingling with PLHA & 53.0 \\
\hline 10 & I would feel ashamed if I have HIV/AIDS & 75.0 \\
\hline 11 & I would not marry HIV/AIDS infected person & 93.0 \\
\hline 12 & PLHA should not be operated for any surgical problem. & 37.0 \\
\hline 13 & PLHA are destined to die sooner or later. & 77.0 \\
\hline 14 & It is alright for men to have pre-marital sex. & 18.0 \\
\hline 15 & $\begin{array}{l}\text { Sexual intercourse should not be committed outside mar- } \\
\text { riage }\end{array}$ & 69.0 \\
\hline 16 & $\begin{array}{l}\text { I would have issue with the use of condom during sexual } \\
\text { intercourse }\end{array}$ & 35.0 \\
\hline 17 & $\begin{array}{l}\text { Using condom during sexual intercourse is a personal choice } \\
\text { and I have no issue with it }\end{array}$ & 52.0 \\
\hline
\end{tabular}

$\%=$ Percentage $\mathrm{N}=$ no. of respondents.

Table 4: Behaviour and practices of the population.

\begin{tabular}{|c|l|c|}
\hline S1. No. & \multicolumn{1}{|c|}{ Behaviour and practices } & Yes \% (N=100) \\
\hline 1 & Ever been exposed to blood transfusion? & 7.0 \\
\hline 2 & Ever abuse non-medical drugs (heroin, cocaine, tablets). & 4.0 \\
\hline 3 & Ever been physically intimate with anyone? & 70.0 \\
\hline 4 & Sex with non-regular sexual partners. & 15.0 \\
\hline 5 & Consistent use of condom (by those reporting non-regular sexual partners). & 18.18 \\
\hline 6 & Will you be able to ask your sexual partner to use condom during sex? & 43.0 \\
\hline 7 & Practice of family planning (for married couples). & 25.46 \\
\hline 8 & Have you ever attended awareness camps/programmes on HIV/AIDS? & 45.0 \\
\hline 9 & Have you ever taken HIV testing? & 44.0 \\
\hline 10 & Will you be willing to go for HIV testing if given a chance? & 43.0 \\
\hline 11 & Do you consider yourself to be at risks for HIV infection? & 11.0 \\
\hline 12 & Does your community gossip a lot against PLHA? & 69.0 \\
\hline 13 & Do people in your society humiliate/insult PLHA? & 15.0 \\
\hline 14 & Are religious positions denied to PLHA in the society? & 58.0 \\
\hline 15 & Will you assign separate utensil to PLHA in the family? & 32.0 \\
\hline 16 & With whom will you confide if you were infected with HIV/AIDS? & 74.0 \\
& 1.Parents & 72.0 \\
& 2.Spouse & 51.0 \\
& 3.Children (adult) & 31.0 \\
& 4.Close person & 25.0 \\
\hline & 6.Friends & \\
\hline
\end{tabular}

$\%=$ Percentage $\mathrm{N}=$ no. of respondents. 
spoken of it independently. A study in Malaysia on knowledge of HIV/AIDS reporting similar findings and attributed the inability to differentiate to the media for portraying HIV and AIDS interchangeably [3]. While this may be partially true, the other factor could be because in Manipur, the term "AIDS" was singularly used during its earlier stage of detection through its peak prevalence in the late 90s'. Prefixing it with "HIV" subsequently followed but by that time, most laymen were already familiar with "AIDS". As has been observed in this study, prefixing it with "HIV" did not seem to make much difference as it fails to register to the common man, its connection either with the disease.

Unlike the findings conducted in an Indian metropolitan slum dweller [18], study participants have good knowledge about HIV/ AIDS transmission and prevention. However, it was marred with misconceptions rooted in socio-religious misinterpretation of the disease. This is because the information about HIV/AIDS is mainly circulated in the community through local gossip and church settings which are often times inaccurate and exaggerated. There is acute lack of HIV/AIDS awareness or education programmes targeted towards local community. Similar findings were reported from Nigeria wherein study participants' fair knowledge on HIV/AIDS transmission and prevention was tainted by social misconceptions [1]. Other studies conducted in Turkey and Sub-Saharan Africa also pointed out a lack of proper sensitization/education among their study participants as the main cause of misconception for HIV/AIDS [19, 20].

Study participants were familiar with HIV/AIDS related symptoms such as weight loss, loss of appetite and complexion. There is a feeling of apprehension that once a person has AIDS, overall physical appearance deteriorates. While it is likely that PLHA will lose complexion, weight and could die prematurely, this fear is misplaced as timely medical intervention could help PLHA to live longer without losing their aesthetic appeal. Therefore, there is a need to properly disseminate correct information on this as such perception contributes to the overall misconception and stigmatisation of HIV/AIDS.

Another stigmatizing factor rooted in socio-religious belief is that HIV/AIDS is seen as the outcome of immorality and sinful lifestyle'. Study participants often invoked the validity of such misgivings by pointing out the predominance of HIV/ AIDS among IDUs', homosexuals, and sexually promiscuous person whose lifestyles are considered sinful and abhorrent. In fact, it was common for Church elders to warn its members from contracting the disease should they stray from Christian 'moral path'. Consequently, there is a strong reservation to give PLHA positions of leadership in the church since good moral conduct is considered a criterion for occupying religious positions. A study on HIV/AIDS in Srinagar (India), Nigeria and South Africa reported similar findings wherein study participants associated HIV/AIDS with morality [10, 21, 22]. Such misconceptions were also responsible for a discrepancy observed between knowledge and behaviour. There is collective 'social consciousness' in which people fear the stigma of being seen together with PLHA. Other studies from developing countries have also attributed discrepancies between knowledge and behaviour to social stigma prevalent in the society [23-25].

The prevalence and seriousness of HIV/AIDS could be seen from the fact that a majority of study participants have known at least one PLHA either from their immediate locality, neighbourhood or at least have known someone that had died of AIDS. As information about PLHA status gets mostly circulated through local gossip, there is a tendency to 'spiced up' with the narrator's imagination without scientific basis. For instance, there was a common perception among some study participants that HIV/ AIDS could be contracted by prolonged use of heroin or the belief that female PLHA live longer than their male counterparts as the virus gets partially flushed out during menstruation.

Despite several local NGOs working for HIV/AIDS, awareness programmes targeting community people were limited. Almost all existing programmes/interventions carried out by local NGOs' were centred on PLHA and their immediate family. However, unless a conducive environment for PLHA is created to bring positive attitude and behavioural change, efforts to fight HIV/ AIDS may not bring the desire outcome. Because in a close knit community like Chandel, where 'social consciousness' takes precedence over medical truth, it is the perception, attitude and behaviour of the local community that have a direct impact on the everyday existence of PLHA.

The consensus fear for the likelihood of PLHA contaminating surgical instruments was compounded by a testimony of a renowned lady gynaecologist from the district hospital who contracted HIV after performing surgical procedure on a female PLHA. Study participants also held the view that since PLHA would die sooner, getting married would simply put another innocent life at risk to meet the same fate. Therefore, it was no surprise that almost all of them favour compulsory testing for HIV prior to marriage.

Preventive behavioural practice towards HIV/AIDS was poor among study participants. Due to socio-cultural upbringing, there is a reservation to discuss sex and sexuality in the open with strangers. A study on geographical perspectives on HIV/AIDS in rural communities of India and a KAP study in Northern India reported similar observation $[21,26]$. However, slightly differing from the observation in rural India [26], discussing sexual activity in the present study was not so rigid once rapport was built. Similarly, there was a mixed response towards the use of condom. Stigma is attached to condom as people associate it with prostitutes and promiscuous person. Additionally, there is a misconception that condom could cause negative impact on women's health. Condom is also believed to obstruct gratifying sexual fulfilment. This is seen as directly conflicting with socio-religious meaning of marriage i.e. procreation and sexual fulfilment. As such, this not only explains the preference of opting for family planning through contraceptive pills and IUD over condom but also the reason behind the alarmingly inconsistent use of condom among study participants. A study on acceptability of male condom: An Indian scenario, reported similar findings with barriers to using condom [28]. In a study in rural Lebanon, study participants attached condom with stigma and reported that condom reduced sexual pleasure [29].

Further analysis of sexual behaviour and practices revealed most study participants considering themselves not at risk for HIV infection despite engaging in risky sexual behaviour. There is a lack of awareness of HIV/AIDS transmission through risky behaviour of sexual partners. Being in a monogamous relationship and living a 'morally upright' lifestyle was perceived as low or no 
risk for HIV infection. All these factors could be the reason for the low uptake of HIV testing. Similar findings were reported from a study among the general staff of a public university in Malaysia [3]. Likewise, a study among the youths in South Africa observed similar perceptions wherein sexual inexperienced was associated with low risk of HIV infection [30].

Although a majority of study participants expressed a willingness to share confidentiality with their parents and spouse in case of contracting the virus, such statement may not necessarily reflect the reality. In a preliminary study carried out among PLHA in Chandel [31], the opposite observation was found. The study reported that most female PLHA found their HIV status either during routine ANC check-up or when their husbands were dying in hospitals. This was in contrast to previous findings in both rural and urban India [32] where majority of PLHA discovered their HIV positive status through voluntary testing.

Regarding sexual behaviour, other studies [13, 33] have pointed out that data collected may contain bias views and may not always reflect the prevailing social reality of sexual behaviour. Since studies on sexual behaviour have been reported to contain bias views, the possibility of the same in the present study could not be ruled out.

\section{Conclusion}

From the study, we can conclude that false socio-cultural and religious notions of $\mathrm{HIV} / \mathrm{AIDS}$ have taken precedence over medical facts leading to stigmatization and discrimination of PLHA in the society. These misconceptions stem from the interplay of several factors such as the predominance of HIV/AIDS among the already 'stigmatized groups of people', incurable clinical condition of HIV/AIDS that incapacitates PLHA prior to their premature death, evidence of deteriorating physical appearance of PLHA, socio-religious misinterpretation of its transmission by sexual route and lack of reliable source of information. The inconsistencies observed between high knowledge on HIV/ AIDS transmission and prevention with negative attitudes and behaviours was a result of such misconceptions impacting community more than the scientific truth.

It is recommended that proper education and awareness on HIV/ AIDS in the context of these socio-religious beliefs is imparted to the community. In this light, it is suggested that religious and community leaders be taken into consideration for any community based HIV/AIDS awareness programmes as these leaders command strong moral and behavioural influence over its community members.

In order to impart a sustainable HIV/AIDS awareness and safe sex practice to the community, there is an urgent need to improve mass media through which correct information on HIV/AIDS and condoms could be regularly disseminated to the public all through the year.

\section{Acknowledgement}

This research work was funded under Rajiv Gandhi National Fellowship by the University Grants Commission (UGC), New Delhi.

\section{References}

[1]. Adebajo SB, Bamgbala AO, Oyediran MA (2003) Attitudes of Health Care Providers to Persons Living with HIV/AIDS in Lagos State, Nigeria. African Journal of Reproductive Health 7 (1): 103-112.

[2]. Ayranci U (2005) AIDS knowledge and attitudes in a Turkish population: an epidemiological study. BMC Public Health 5: 95.

[3]. Tee Y, Huang M (2009) Knowledge of HIV/AIDS and attitudes towards people living with HIV among the general staff of a public university in Malaysia. Journal of Social Aspects of HIV/AIDS 6 (4): 179-187.

[4]. UNAIDS (2010) Global Report: UNAIDS Report on the Global AIDS Epidemic.

[5]. Lal SS, Vasan RS, Sarma PS, Thankappan KR (2000) Knowledge and Attitude of College Students in Kerala towards HIV/AIDS, Sexually Transmitted Diseases and Sexuality. The National Medical Journal of India 13 (5): 231-236.

[6]. Ghosh J (2002) A Geographical Perspective on HIV/AIDS in India. Geographical Review 92 (1): 114-126.

[7]. Umeh CN, Essien EJ, Ezedinachi EN, Ross MW (2008) Knowledge, Beliefs and Attitudes about HIV/AIDS related issues, and the Sources of Knowledge among Health Care Professionals in Southern Nigeria. Journal of Research on Social Health 128 (5): 233-239.

[8]. Bruyn MD (1992) Women and AIDS in Developing Countries. Social Science 34 (3): 249-262.

[9]. Norman LR, Carr R, Jiménez J (2006) Sexual Stigma and Sympathy: Attitudes towards Persons Living with HIV in Jamaica. Culture, Health and Sexuality 8 (5): 423-433.

[10]. Visser MJ, Makin JD, Lehobye K (2006) Stigmatizing attitudes of the Community towards people living with HIV/AIDS. Journal of Community and Applied Social Psychology 16(1): 42-58.

[11]. Yoder PS (1997) Negotiating Relevance: Belief, Knowledge and Practice in International Health Projects. Medical Anthropology Quarterly 11 (2): 131146.

[12]. Fagbamigbe AF, Akinyemi JO, Adedokun BO, Bamgboye EA (2011) Gender variation in self-reported likelihood of HIV infection in comparison with HIV test results in rural and urban Nigeria. AIDS Research and Therapy 8: 44.

[13]. Parker RG, Herdt G, Carballo M (1991) Sexual culture, HIV Transmission and AIDS Research. The Journal of Sex Research 28 (1): 77-98.

[14]. Nayar M, Bhatnagar N, Arora S (2007) Adolescents' Knowledge and Awareness abo ut issues related Sexuality and HIV/AIDS. Indian Journal of Industrial Relations 43 (1): 69-86.

[15]. Boileau C, Vissandjee V, Nguyen V-K, Rashed S, Sylla M, \& Zunzunegui MV (2008) Gender Dynamics and Sexual Norms among Youth in Mali in the Context of HIV/AIDS Prevention. African Journal of Reproductive Health 12 (3): 173-184

[16]. Manipur State AIDS Control Society (2011) Epidemiological Analysis of HIV/AIDS in Manipur. Imphal.

[17]. NACO \& Ministry of Health and Family Welfare Annual Report (20102011). Government of India, New Delhi.

[18]. Kalasagar M, Sivapathasundharam B, Einstein TB (2006) AIDS Awareness in an Indian Metropolitan Slum Dweller: A KAP (Knowledge, Attitude, Practice) Study. Journal of Community Medicine 17 (2): 66-69.

[19]. Özcebe H (2002) Needs Assessment for HIV/AIDS Education: The Level of Knowledge about Transmission in some Risks Groups in Turkey. Annals of Saudi medicine 22 (3-4): 172-176.

[20]. Hartwig KA, Kissioki S, Hartwig CD (2006) Church leaders confront HIV/ AIDS stigma. Journal of Community Applied Social Psychology 16(6): $492-$ 497.

[21]. Gaash B, Ahmad M, Kasue R, Bashir S (2003) Knowledge, Attitude and beliefs on HIV/AIDS among the Female Senior Secondary Students in Srinagar District of Kashmir. Health and Population- Perspectives and Issues 26 (3): 101-109.

[22]. Smith DJ (2004) Youth, Sin and Sex in Nigeria: Christianity and HIV/ AIDS-related Beliefs and Behaviour among Rural-Urban migrants. Culture, Health and Sexuality 6 (5): 425-437.

[23]. Gray LA, Seracino M (1999) College students' Attitudes, Beliefs, and Behaviours about AIDS: Implications for Family life educators. Family Relations 40 (3): 258-263.

[24]. Lim VKG, Loo GL (2000) HIV and the Work Place: Organisational Consequences of Hiring Persons with HIV and Attitudes towards Disclosure of HIV-related Information. International Journal of Manpower 21 (2): 129140 .

[25]. Balaganesh G, Ramakrishna Y, Rao YS, Babu VS (1993) A Study on the Awareness about AIDS/STDS in Indian Communities. Indian J Sexual. 
Transm Dis 14: 33-43.

[26]. Ghosh J (2002) A Geographical Perspective on HIV/AIDS in India. Geographical Review 92 (1): 114-126.

[27]. Goyal RC, Kulkarni AT, Somasundaram KV (1994) AIDS Awareness among Rural Community-A Study. Swasth Hind 18 (11-12): 266-262.

[28]. Donta B, Begum S, Naik DD (2014) Acceptability of male condom: An Indian scenario. Indian Journal of Medical Research 140:152-156.

[29]. Kulczycki A (2004) The Socio-cultural Context of Condom Use within Marriage in Rural Lebanon. Studies in Family Planning 35 (4): 246-260.

[30]. Anderson KG, Beutel AM, Maughan-Brown B (2007) HIV Risks Perceptions and First Sexual Intercourse among Youth in Cape Town, South Africa. International Family Planning Perspective 33 (3): 98-105.

[31]. Lamkang AS, Joshi PC, Singh MM (2009) Assessing the Quality of Life and Needs of HIV/AIDS Patients in Manipur: A Preliminary Study. Journal of
Community Disease 41 (4): 221-227.

[32]. Pradhan BK, Sundar R, Singh SK (2006) Socio-economic Impacts of HIV and AIDS in India. NACO, NCAER, UNDP, New Delhi.

[33]. Bui TD, Pham CK, Pham TH, Hoang LT, Nguyen TV, Vu TQ, Detels R (2001) Cross-sectional study of sexual behaviour and knowledge about HIV among urban, rural, and minority residents in Vietnam. Bulletin of the World Health Organisation 79 (1): 15-21.

[34]. Negi K.S, Khandpal SD, Kumar A, Kukreti M (2006) Knowledge, Attitude and Perception about HIV/AIDS among Pregnant Women in Rural Area of Dehradun. JK Science 8 (3):133-138. 